\title{
Enhancement The Growth of Snakehead (Channa striata) with Addition of Dragon Fruit Peel Flour to The Diet
}

\author{
Rakhmawati $^{1 *}$, Tulas Aprilia², Agung Kurniawan ${ }^{2}$ \\ ${ }^{I}$ Department of Aquaculture, Lampung State Polytechnic, Lampung, Indonesia \\ ${ }^{2}$ Department of Fish Hatchery Technology, Lampung State Polytechnic, Lampung, Indonesia \\ *Corresponding Author: rakhmawati@polinela.ac.id
}

Article history

\begin{tabular}{llll}
\hline Received & Received in revised form & Accepted & Available online \\
27 May 2021 & 23 August 2021 & 04 September 2021 & 18 September 2021 \\
\hline
\end{tabular}

Abstract: Snakehead (Channa striata) is a fish that grows relatively slowly, but is a typical Sumatran fish with high albumin content and economic value. This makes this fish a very prospect to be developed. Meanwhile, dragon fruit peel is one of the wastes that can be used for diet raw materials and contains vitamins and minerals that have the potential to be useful for increasing growth in fish. This study aims to determine the growth performance of snakehead fed by adding dragon fruit peel flour. This study used test animals, namely snakehead fish juvenile with the size of $1.06 \pm 0.02 \mathrm{~g} /$ fish. The experiment of fish reared in aquarium measuring of $35 \mathrm{~cm} \mathrm{x} 45 \mathrm{~cm} \times 90 \mathrm{~cm}$, filled with water as high as $15 \mathrm{~cm}$ without aeration. The experiment diets consisted of 5 types, namely feed added with $0 \%$ dragon fruit flour (control); $0.5 ; 1.0 ; 1.5$ and $2.0 \%$ of feed. Each treatment was repeated three times. Snakehead was reared for 60 days and fed three times a day on an ad satiation basis. The parameters observed in this study were the survival rate and growth performance of snakehead fish. The results showed that the survival rate between treatments was not significantly different, namely in the range of $97.76-100 \%$. Meanwhile, the specific growth rate and feed efficiency of snakehead which added $2 \%$ to the diets were the highest, namely $8.66 \pm$ $0.04 \%$ /day and $67.83 \pm 2.31 \%$ /day. The conclusion of this study was the addition of dragon fruit peel flour at $2 \%$ enhanced the growth performance of snakehead.

Keywords: snakehead, addition, dragon fruit peel flour, growth

\section{Introduction}

Snakehead has high economic value [1] and is a popular local fish, especially in the Sumatra region [2], including Lampung. This fish has started to be cultured but still relies on catch and the price is relatively high compared to other freshwater fish. The albumin content is found in snakehead fish [3] which is useful for accelerating wound healing. The problem that exists in this snakehead fish farming is its relatively slow growth, so it requires solutions from various aspects of cultivation. One of them is in terms of feed, efforts are made to find alternative feed solutions that can increase the growth of this snakehead fish.

When the COVID 19 pandemic hit the world, consumption of fresh fruit increased. This is done to increase body immunity. Fresh fruit production has increased to meet domestic and export needs compared to the previous year. In January-May 2020 the export demand was 375.000 tons [4]. The fruit requested is dragon fruit, banana, mango, and rambutan from several countries. Dragon fruit is a fruit that is widely produced by farmers in Indonesia. Most of the use of dragon fruit is in the flesh, while the peel becomes waste. This waste can be used as additives to feed. The ratio between dragon fruit as a whole with the peel is $1: 0.20$ [5] or $22 \%$ of the peel compared to the whole [6][7].

Dragon fruit peel waste contains polyphenols which are antioxidants [7]. The water content in dragon fruit peel is about $92 \%$, the rest is protein, fat, and ash and the content of betacyanin and pectin is relatively high [6]. Sasina reported that $100 \mathrm{~g}$ of dragon fruit peel contains $0.71 \mathrm{~g}$ fiber, $6.7 \mathrm{mg}$ betacyanin, total flavonoids of $220.28 \mathrm{mg} \mathrm{CE}$, and total phenol of $561.76 \mathrm{mg}$ GAE [8]. Vitamin C, saponins, alkaloids, steroids, tannins and flavonoids are contained in dragon fruit peel extract [9]. The antioxidant activity of this waste is considered higher than that of the fruit [10]. The content of antioxidants and vitamin $\mathrm{C}$ in dragon fruit peel has the potential as a nutrient that can support increased growth and health in cultured fish.

Research on the use of dragon fruit peel has been carried out on several fish. [11] reported that adding $1 \%$ dragon fruit peel to clownfish feed resulted in better color and growth quality than other treatments. The color of black and orange koi carp increases with the addition of this flour $15 \%$ of feed [12] and increases growth [13]. Kidney damage can be minimized in goldfish infected with Aeromonas hydrophilla bacteria by adding dragon fruit peel extract $6 \mathrm{ml} /$ gram [14].

One of the efforts that can be made to increase growth and immune response in snakehead fish is 
through a nutritional approach. This effort is expected to reduce slow growth and susceptibility to stress. The content of vitamins, amino acids and antioxidant compounds in dragon fruit peel is thought to be able to solve problems in snakehead fish culture. Red dragon fruit peels contain antioxidants that support fish health. This activity is supported by several bioactive components it contains [15]. Flavonoids, polyphenols, vitamins C, $\mathrm{E}, \mathrm{B}$ and carotene. This bioactive content is very necessary for fish health. Vitamin $\mathrm{C}$ protects cells or tissues from oxidative stress due to free radicals. This vitamin can inhibit the oxidation of fats, proteins and DNA. Carotenoid supplementation can increase growth in rainbow kuromui fish, antioxidant activity of carotene reduces superoxide dismutase (SOD) and malonyl dialdehyde (MDA) indicating detoxification of ROS [16]. Therefore, further research needs to be done because to determine the effect of dragon fruit peel in feed on growth performance in snakeheads.

\section{Material and Methods}

\subsection{Materials}

The materials used in this study were first, snakehead juveniles with an average weight of 1.06 \pm 0.02 grams were obtained from a farmer who collects from Pringsewu Regency, Lampung Province, Indonesia. Second, commercial feed with \pm $32 \%$ protein content. Third, the dragon fruit peel used comes from red dragon fruit. The fourth is the binder, which is used is progol and also distilled water. Next are materials for proximate testing and materials for water quality checks.

\subsection{Methods}

\subsubsection{Preparation of experiment feed}

The dragon fruit used is $700-800 \mathrm{~g} /$ fruit which is obtained from cultivation in Lampung Province. The preparation of dragon fruit peel flour refers to according to [5]. Dragon fruit is weighed first and then weeded by washing and removing the scales. Furthermore, the peel is separated from the pulp and weighed. The next step is the peel is thinly sliced with a thickness of $\pm 1 \mathrm{~mm}$, placed on a baking sheet and then oven at $70^{\circ} \mathrm{C}$ for 7 hours. Once cool, the dragon fruit peel is mashed with a blender and mortar and then sieved. Dragon fruit peel flour (DFPF) is ready to be mixed into the experiment feed.

The experiment feed used consisted of 5 types, namely feed with the addition of DFPF. The feed used is commercial feed with a protein content of
$32 \%$. Commercial feed is added with dragon fruit peel flour according to the dosage with a binder and distilled water and then dried and dried for 5-7 hours. After that the feed is stored in plastic jars and used according to the treatment. The treatment $(\mathrm{T})$ in this study were commercial feed added 0\% DFPF (T1), $0.5 \%$ (T2), $1.0 \%$ DFPF (T3), $1.5 \%$ DFPF (T4) and $2.0 \%$ (T5). DFPF has been mixed in commercial feed according to the percentage of treatment $/ \mathrm{kg}$ feed

\subsubsection{Experiment animals and rearing}

Before the study, snakehead was reared for 1 week and given commercial feed (32\% protein) for acclimatization to the research conditions. The test fish were reared for 60 days. At the beginning of the study, individual fish were weighed and distributed randomly into 15 rectangular aquariums $(35 \times 45 \times 90 \mathrm{~cm})$ with a density of 10 fish/aquarium. Feeding with a feeding rate of $5 \%$ three times a day (around 07.00, 12.00 and 17.00 WIB). Media for rearing water without aeration with a water change of $25 \%$ and feces on siphon every day.

\subsubsection{Experimental variable and analytical procedures}

This study used a completely randomized design with five feed treatments and three replications. Experimental variables in the current study was survival rate, initial and final biomass, feed consumption, specific growth rate and feed efficiency. Data were analyzed using a one-way ANOVA analysis of variance. The program used is IBM SPSS 26. If there is data that shows a significant difference, it will be followed by the Duncan test, comparing $\mathrm{T} 1$ with $\mathrm{T} 2, \mathrm{~T} 3, \mathrm{~T} 4$ and $\mathrm{T} 5$. The 5\% significance level was considered in all statistical analysis.

\subsection{Data Analysis}

The survival rate was calculated by the number of fish at the beginning and the end of rearing. Fish biomass was weighed at the start and end of maintenance. The amount of feed consumption is calculated every week based on the percentage of feeding rates given during rearing. Feed efficiency and specific growth rate were calculated based on [17].

\section{Results and Discussion}

The survival rate of snakehead which was given the addition of dragon fruit peel flour showed not significantly different between all of the treatments as shown in Figure 1. 


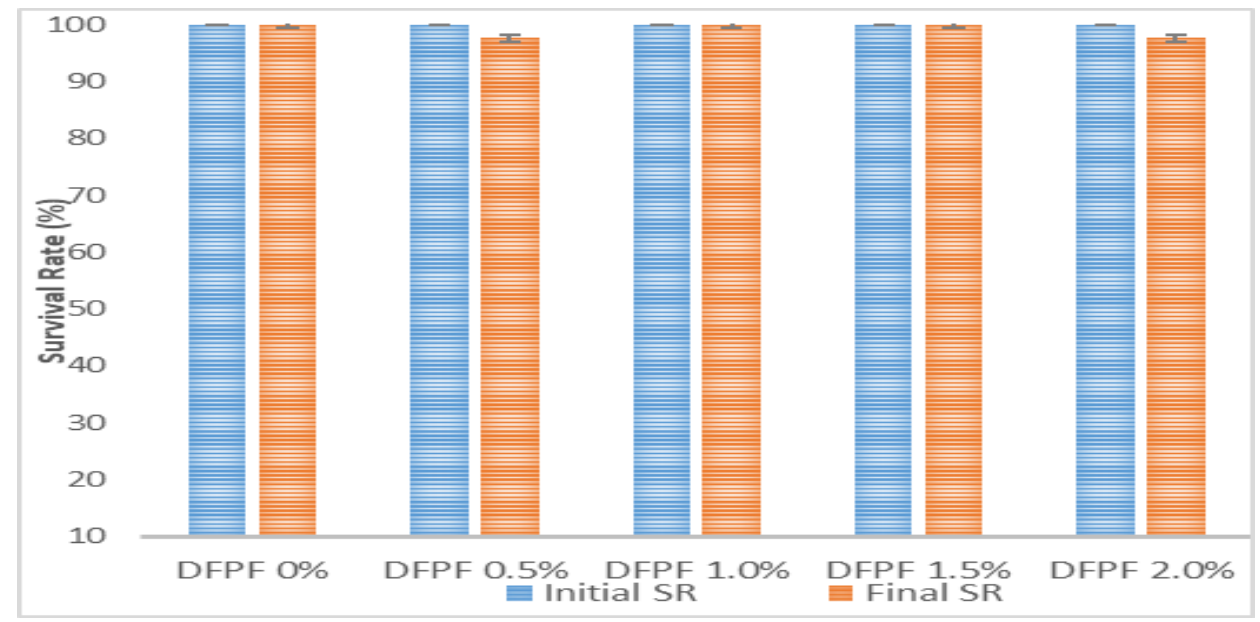

Figure 1. Survival Rate of Snakehead with Addition of Dragon Fruit Peel Flour (DFPF)

The survival rate of snakehead which was given addition and without the addition of DFPF in the feed resulted in high yields. This means that all treatments can live well with different feed treatments and are classified as good maintenance because the survival rate ranges from $96.7-100 \%$.

It is assumed that the snakehead has sufficient nutritional needs and is conducive to the quality of its maintenance water. The content of the commercial feed given contained about $32 \%$ protein and there was also the addition of protein in the treated feed which came from DFPF. This protein content is sufficient for fish growth. While the water quality parameters found were temperatures ranging from 27 $-30^{\circ} \mathrm{C}, \mathrm{pH}$ ranging from $6.5-7$, dissolved oxygen ranging from 5.3 to $5.6 \mathrm{mg} / 1$ and ammonia levels from 0.0015 to $0.0017 \mathrm{mg} / 1$. Measured water quality parameters are in the tolerance range for snakehead fish [18][19].

The growth of snakehead which was given the addition of dragon fruit peel flour showed a significant increase in changes in the initial and final weight means as shown in Figure 2.

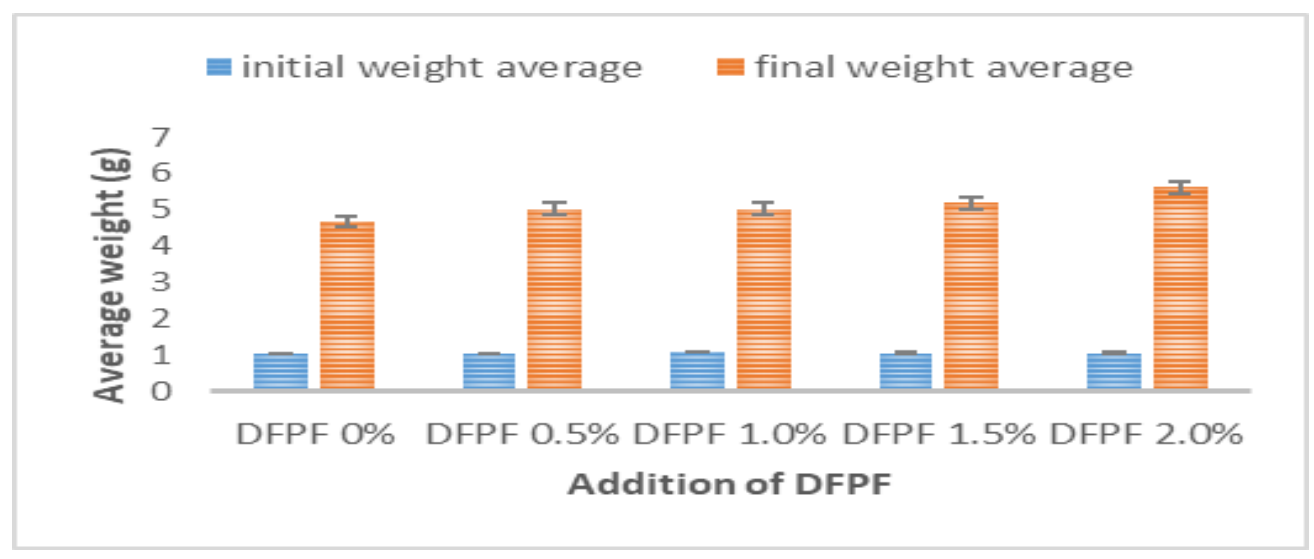

Figure 2. Enhancement Growth of Snakehead with Addition of Dragon Fruit Peel Flour (DFPF)

The average growth of snakehead weight for 60 days in the addition of dragon fruit peel flour treatment at a percentage of 0.5 and $1.0 \%$ showed no significant difference compared to control. Meanwhile, the addition of dragon fruit peel flour as much as 1.5 and $2 \% / \mathrm{kg}$ of feed resulted in higher growth than control and was statistically significant. However, adding $2 \% / \mathrm{kg}$ of feed resulted in the best growth. The amount of feed consumption and feed efficiency in snakeheads is presented in Figure 3. 


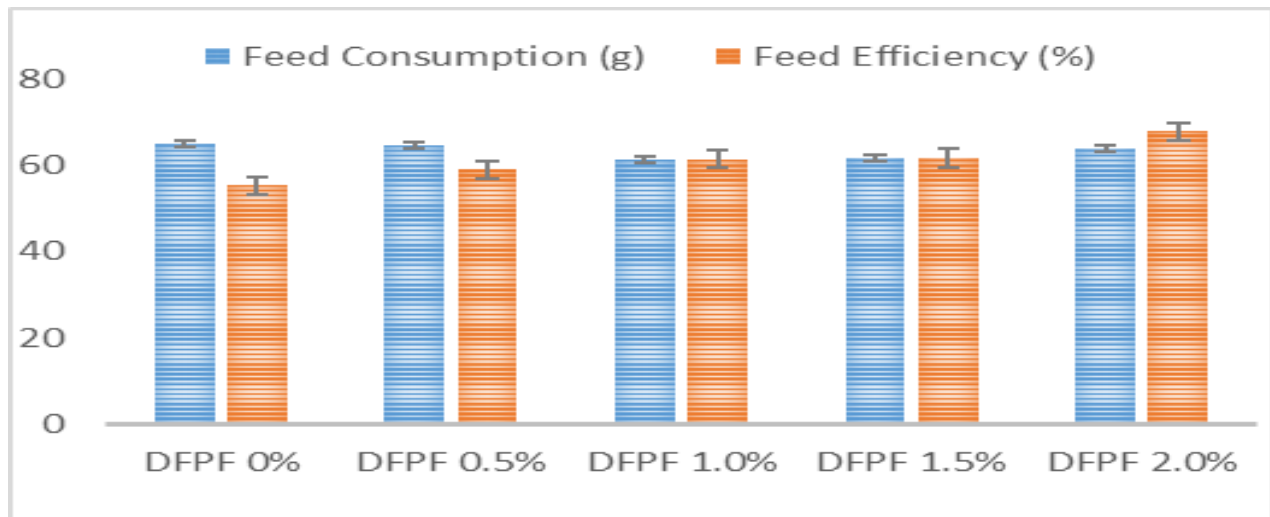

Figure 3. Feed Consumption and Feed Efficiency of Snakehead with Addition of Dragon Fruit Peel Flour (DFPF)

The amount of feed consumption did not differ significantly in all treatments. On the other hand, feed efficiency with the addition of dragon fruit peel flour was significantly higher at the addition of $2 \%$ to the feed, while the other treatments were not significantly different from the control. The increase in biomass weight and specific growth rate in the utilization of feed on snakehead added with dragon fruit peel flour is presented in Table 1.

Table 1. Growth of the Snakehead Fed with the Addition of Dragon Fruit Peel Flour

\begin{tabular}{cccccc}
\hline \multirow{2}{*}{ Parameters } & \multicolumn{5}{c}{ Dragon Fruit Peel Flour (DFPF) Addition in Feed } \\
\cline { 2 - 6 } & $0 \%$ DFPF & $0.50 \%$ DFPF & $1.0 \%$ DFPF & $1.5 \%$ DFPF & $2.0 \%$ DFPF \\
\hline IB (gr) & $10.43 \pm 0.08 \mathrm{a}$ & $10.53 \pm 0.08 \mathrm{a}$ & $10.70 \pm 0.06 \mathrm{a}$ & $10.57 \pm 0.12 \mathrm{a}$ & $10.63 \pm 0.03 \mathrm{a}$ \\
FB (gr) & $46.33 \pm 0.28 \mathrm{a}$ & $48.57 \pm 0.27 \mathrm{ab}$ & $50.25 \pm 0.38 \mathrm{abc}$ & $51.88 \pm 2.36 \mathrm{bc}$ & $54.04 \pm 1.76 \mathrm{c}$ \\
SGR (\%) & $7.74 \pm 0.08 \mathrm{a}$ & $8.13 \pm 0.20 \mathrm{a}$ & $8.04 \pm 0.04 \mathrm{a}$ & $8.27 \pm 0.03 \mathrm{a}$ & $8.66 \pm 0.04 \mathrm{~b}$ \\
\hline
\end{tabular}

*) Standard deviation values followed by the different letter in the same row indicate a significantly different effect (P $<0.05)$, IB: initial biomass and FB: final biomass.

Significant enhancement in biomass was obtained in the DFPF added of 1.5 and $2.0 \%$ / $\mathrm{kg}$ of feed. Meanwhile, the amount of feed consumption did not differ significantly in all treatments. While the feed efficiency with the addition of dragon fruit peel flour was significantly higher at the addition of $2 \%$ to the feed, while the other treatments were not significantly different from the control.

The addition of dragon fruit peel flour also affect on the specific growth rate and feed efficiency of snakeheads. It can be seen in the results in Table 1, the addition of $2 \%$ DFPF / $\mathrm{kg}$ feed significantly increased the specific growth rate and feed efficiency. However, the addition by a smaller number does not affect both parameters.

Dragon fruit peel flour contains about $5 \%$ crude protein so that when it is added to commercial feed there is an increase in protein content. The increase in protein was obtained by $2-3 \%$ in the commercial feed when $0.5-2.0 \%$ DFPF was added to feed [5]. The increase in protein in the treated feed had a positive correlation with the increase in the specific growth rate and the level of feed efficiency. Protein is very necessary for the growth phase. The addition of DFPF in snakehead fish feed led to an increase in growth performance.

In addition, dragon fruit peel contains antioxidant compounds in the form of vitamin C, flavonoids, tannins, alkaloids, steroids and saponins [9]. The addition of vitamin $\mathrm{C}$ to snakehead fish feed increases growth as research [20] as well as other fish [21][22] [23], while flavonoids, tannins, alkaloids, steroids and saponins are antioxidants that can increase endurance [24][25]. These two things can indirectly support the growth performance of snakehead fish.

Vitamin $\mathrm{C}$ and flavonoids are components that can prevent oxidative stress. Vitamin $\mathrm{C}$ can easily capture reactive oxygen and nitrogen species, such as superoxide, hydroperoxyl radicals, and nitrogen dioxide radicals, thereby preventing damaging reactions to biomolecules. In the body, vitamin $\mathrm{C}$ can protect long-chain unsaturated fatty acids, vitamin $\mathrm{E}$, and vitamin A from oxidation [26]. This is an important function because long-chain unsaturated fatty acids and vitamin $\mathrm{E}$ are essential components for maintaining the integrity of cell membranes. While flavonoids can inhibit the enzymes responsible for producing superoxide anion radicals, the reaction terminates and extinguishes superoxide anion radicals [27].

Antioxidants in dragon fruit peel can inhibit superoxide anion radicals. Flavonoids in dragon fruit peel play a role in hydrogen atoms to capture hydroxyl radicals to make them non-reactive and inhibit free radicals [28]. Red dragon fruit peel (1 $\mathrm{mg} / \mathrm{kg}$ ) can inhibit $83.48 \%$ of free radicals [29]. The 
addition of 5\% dragon fruit peel in the ration could reduce cholesterol, LDL, triglycerides, and maintain HDL effectively in broiler chicken blood [30]. Antioxidant activity can increase growth and health in rainbow caramoi [16] and red tilapia [31][32].

\section{Conclusion}

Best enhancement of the growth of snakehead was obtained from the addition of dragon fruit peel flour of $2 \%$ in the feed. The improved growth performance was mainly the increase in the final biomass, the specific growth rate and the feed efficiency.

\section{Acknowledgment}

We would like to thank Lampung State Polytechnic had funded this study through DIPA 2020.

\section{References}

[1] A. Saputra, T. Budiardi, R. Samsudin, and M. D. Rahmadya, "Growth performance and survival of snakehead Channa striata juvenile with different stocking density reared in recirculation system," Jurnal Akuakultur Indonesia, vol. 17, no. 2, pp 104-112. 2018.

[2] D. Muthmainnah, "Hubungan panjang, berat dan factor kondisi ikan gabus (Channa striata Bloch, 1793) yang dibesarkan di rawa lebak, Provinsi Sumatera Selatan," Depik, vol 2, no 3, pp 184-194. Des 2013.

[3] Purnawati, D. Djokosetiyanto, K. Nirmala, and R. Affandi, "Survival and growth responses of snakehead fish Channa striata Bloch. Juvenile in aerated and unaerated acid sulfate water," Jurnal Akuakultur Indonesia, vol 16, no 1, pp 60-67. 2017.

[4] Badan Pusat Statistik. 2019. Statistik tanaman buah-buahan dan sayur-sayuran tahunan. Available:

http://www.bps.go.id/publication/2019/10/07/1 $846605363955649 \mathrm{c} 8 \mathrm{f} 6 \mathrm{dd} 6 \mathrm{~d} /$

[5] T. Aprilia and Rakhmawati, "Quality improvement of feed chemical composition with the addition of dragon fruit skin flour (Hylocereus polyrhizus)," Jurnal Rekayasa dan Teknologi Budidaya Perairan, vol 9, no. 2. 2021.

[6] A. R. Sari and R. Hardiyanti "Antioxidant level and sensory of dragon fruit (Hylocereus undalus) peel tea infusion made by partially fermented process," Agroindustrial Journal, vol. 2, issue I, pp 63-68. 2013.

[7] B. Jamilah, C. E. Shu, M. Kharidah, M. A. Dzulkifly, and A. Noranizan "Physico-chemical characteristics of red pitaya (Hylocereus polyhizus) peel," International Food Research Journal, vol. 18, pp. 279-286. 2011.
[8] S. Sangthawan, "Prebiotic Activity and Bioactive Compounds of The Enzymatically Depolymerized Thailand-Grown Mangosteen Aril," Journal of Food Research, vol. 1, no. 1, pp 268-276. 2012.

[9] M. I. Noor, E. Yufita, and Zulfalin, "Kandungan ekstrak kulit buah naga merah menggunakan fourier transform infrared (FTIR) dan fitokimia," Journal of Aceh Physics Society, vol. 5, no.1, pp. 14-16. 2016.

[10] R. Nurliyana, I. S. Zahir, K. M. Suleiman, M. R. Aisyah, and K. K. Rahim, "Antioxidant study of pulps and peels of dragon fruits: a comparative study," International Food Research Journal, vol. 17, pp. 365-367. 2010.

[11] D. Simamora, "Pengaruh konsentrasi tepung kulit buah naga merah (Hylocereus polyrhizus) pada pakan terhadap peningkatan warna dan pertumbuhan ikan badut (Ampiphrion ocellaris)," Skripsi, Program Studi Akuakultur, FPIK, UBT, Tarakan, Indonesia, 2019.

[12] N. Kalidupa, A. Kurnia, and I. Nur, "Studi pemanfaatan tepung kulit buah naga merah (Hylocereus polyrhizus) dalam pakan terhadap pewarnaan ikan koi (Cyprinus carpio L.)," Media Akuatika, vol. 3, no. 1, pp. 590-597. 2018.

[13] T. R. Efianda, Y. Yusnita, N. Najmi, K. R. Ananda, and F. Saputra, "Pengaruh kulit buah naga (Hylocereus polyrhizus) dalam pakan terhadap kinerja reproduksi ikan koi (Cyprinus carpio)," Jurnal Perikanan Tropis, vol. 7, no. 2. 2020.

[14] N. Sudrajat, "Pengaruh pemberian ekstrak kulit buah naga (Hylocerus polyrhizus) terhadap perubahan histopatologi ginjal ikan nila (Oreochromis niloticus) yang diinfeksi bakteri Aeromonas hydrophila," Skripsi, Jurusan Perikanan, UMM, Malang, Indonesia. 2019.

[15] F. Le Bellec, F. Vailant, and E. Imbert, "Pitahaya, (Hylocereus spp): a new fruit crop, a market with a future," Journal of Fruit, vol. 6, no. 4, pp 237-250. 2006

[16] N. Meilisza, M. A. Suprayudi, D. Jusadi, M. Zairin Jr, I. M. Artika, and N. B. P. Utomo, "Enhancement of colour quality, growth, and health status of rainbow Kurumoi fish Melanotaenia parva through dietary synthetic carotenoids supplementation," Jurnal Akuakultur Indonesia, vol. 18, no. 1, pp 56-69. 2019

[17] N. Zonneveld and E. A. Huisman, J. H. Boon, Prinsip-prinsip budidaya ikan, Jakarta, Indonesia : Gramedia Utama, 218p, 1991.

[18] Balai Perikanan Budidaya Air Tawar Mandiangin. 2014. Naskah akademik ikan gabus haruan (Channa striata Bloch 1793) hasil domestikasi. Available https://www.djpb.kkp.go.id. 
[19] D. Puspaningsih, E. Supriyono, K. Nirmala, I. Rusmana, C. Kusmana, and A. Widiyati. The dynamics of water quality during culture of snakehead fish (Channa striata) in the aquarium," Omni-Akuatika, vol. 14, no. 2, pp. 123-131. 2018.

[20] T. H. Alfisha, M. B. Syakirin, T. Y. Mardiana, Linayati, and B. D. Madusari, "Penambahan vitamin C pada pakan buatan terhadap pertumbuhan benih ikan gabus (Channa striata)," Jurnal Litbang Kota Pekalongan, vol. 19, pp. 91-97. 2020.

[21] O. K. Ghadamosi, E. A. Fasakin, and O. T. Adebayo. 2013, "Clinical changes observed in Clarias gariepinus (Burchell 1822) fed varying levels of ascorbic acid supplementation," African Journal Agriculture Research, vol. 8, no. 30, pp. 4122-4127. 2013.

[22]. M. Faramarzi, "Effect of dietary vitamin $\mathrm{C}$ in growth and feeding parameters, carcass composition and survival rate of common carp (Cyprinus carpio)," Global Veterinaria, vol. 8, no. 5, pp. 507-510. 2012.

[23] N. Kursistiyanto, N. Anggoro, and Suminto, "Penambahan vitamin $\mathrm{C}$ pada pakan dan pengaruhnya terhadap respon osmotic, efisiensi pakan dan pertumbuhan ikan nila gesit (Oreochromis sp.) pada media dengan osmolaritas berbeda," Jurnal Perikanan Fakultas Ilmu Perikanan dan Kelautan Universitas Diponegoro, vol. 8, no. 2, pp. 66-75. 2013.

[24] Y. Mulyani, E. Bachtiar, and M. U. Kurnia, "Peranan senyawa metabolit sekunder tumbuhan mangrove terhadap inveksi bakteri Aeromonas hydrophilla pada ikan mas (Cyprinus carpio L.)," Jurnal Akuatika, vol. 4, no. 1, pp 1-9. Mar 2013.

[25] N. M. G. R. Nomer, A. S. Duniaji, and K. A. Nocianitri, "Kandungan senyawa flavonoid dan antosianin ekstrak kayu secang (Caesalpinia sappan L.) serta aktivitas antibakteri terhadap
Vibrio cholerae," Jurnal Ilmu dan Teknologi Pangan, vol. 8, no. 2, pp 216-225, June 2019.

[26] S. Chambial, S. Dwivedi, K. K. Shukla, P. J. John, and P. Sharma, "Vitamin C in Disease Preventation and Cure: An Overview," Indian Journal Clinic Biochemical, vol 28, no. 4, pp 314 - 328. 2013.

[27] T. Y. Kim, E. Leem, J. M. Lee, and S. R. Kim, "Control of Reactive Oxygen Species for the Prevention of Parkinson's Disease: The Possible Application of Flavonoids," Antioxidants, vol. 9, no. 7. 2020.

[28] D. Amic, D. Davidovic-Amic, D. Beslo, and N. Trinasjtic, "Structure-radical scaveging activity relationshipof flavonoids," Croatica Chemica Acta 76, 2003

[29] R. Nurliyana, Z. I. Syed, S. K. Mustapham, M. R. Aisyah, and R. K. Kamarul, "Antioxidant study of pulp and peel dragon fruits: a comparative study," International Food Research Journal, vol. 17, 365-375. 2010

[30] M. E. Mahata, Y. Mahlil, Y. Fajri, R. Anditia, and R. Yose, "The utilization of red dragon fruit (Hylocereus polyrhizus) peel as broiler feed", Abstract summary, International Congress and General Meeting. Society for Southeast Asian Agricultural Science (ISSAAS) in Collaboration with SAEDA, Tokyo University of Agriculture and JSTA, Tokyo, Japan. 2014.

[31] Rakhmawati, M. A. Suprayudi, M. Setiawati, Widanarni, M. Zairin Jr, and D. Jusadi, "Respons stres transportasi pada ikan nila merah yang diberikan pakan berkromium," Jurnal Akuakultur Indonesia, vol. 17, no. 1, pp $16-25.2018$

[32] Rakhmawati, M. A. Suprayudi, M. Setiawati, Widanarni, M. Zairin Jr, and D. Jusadi, "Effect of dietary chromium to improve immune response in red tilapia (Oreochromis sp.)," AACL Bioflux, vol 14, no 3, pp 1747-1757. 2021. 